\title{
A Historical Consideration into Two Perspectives on Culture Revealed in the New Korean Wave Discourse
}

\author{
Jimin Jung
}

\begin{abstract}
Gangnam Style's worldwide success has marked the epitome of the new "hallyu" (Korean wave) trend that dates back to the late 2000s. Its origin dates back to 1990s, during which the Korean TV shows became popular in greater Asia. The next wave of 2000s introduced Korean music, K-Pop, to the world, to a wider audience beyond Asia. In Korea, the unprecedented success of Psy's Gangnam Style ignited a heated discussion on hallyu's effect, marketing strategies and future. The Korean government labeled the past two decades of hallyu as hallyu 1.0 and 2.0 . respectively. In the new decade, the government intends to create hallyu 3.0, aiming to promote Korean culture beyond the narrow channels of K-Pop and K-Drama. After the recent wave of Korean craze has passed, many have raised criticisms against the current discourses on the new hallyu. Most of these disapprove of the cultural imperialism and cultural nationalism that underlie the current discourses on hallyu, and calls for a more open, global framework tolerant of cultural diversity. These criticisms are reasonable and necessary; Koreans' cultural nationalistic fervor is certainly a problem. However, they overlook the inseparability between cultural nationalism and transnational cultural trend. This study looks at cultural nationalism as a constant in transnational cultural interaction, and treats it as a subject worth exploring. To understand transnational cultural phenomenon in case of Korea, the best historical example is Japan, a past colonial power which had ruled Korea. Thus this study attempts to further the critical discourse on hallyu by comparing the Japanese wave discourses of Korea and the new hallyu discourse of $2010 \mathrm{~s}$.
\end{abstract}

Index Terms-Korean wave (hallyu), Japanese wave (ilryu), nationalism, transnational cultural phenomenon.

\section{INTRODUCTION: TRANS-NATIONAL HALLYU, NATIONAL HALLYU DisCOURSE}

In its essence, culture is trans-national. It spreads across borders, and creates new meanings by mixing with other cultures; tracing its origin does not give us a nationality. However, we label culture with a nationality. Cultural assimilation then becomes a sacrilegious act tainting the "pure" culture. Nationalism always enters cultural discourse on assimilation.

The name "Hallyu discourse," which refers to Koreans' responses to the Korean wave, cannot be free from nationalism. Since the 1990s during which marked the start of hallyu with Korean TV-shows (K-TV, or K-Drama) hallyu discourse has always existed, but this study focuses on the new hallyu discourse which originated at the onset of 2010 s

Manuscript received May 6, 2014; revised July 12, 2014. This work was supported in part by Brain Korea 21 Plus Program of Department of Korean Language and Literature in Yonsei University.

Jimin Jung is with the Department of Korean Language and Literature at Yonsei University, Seoul, Korea (e-mail: anyria@ naver.com). when the Korean music (K-Pop) became more popular in the global scene. The reaction to the new hallyu discourse has created much buzz, as much positive as negative. The Korean government labeled the past two decades of hallyu as hallyu 1.0 and 2.0. respectively. In the new decade, the government plans hallyu 3.0, which looks to promote Korean culture beyond the narrow channels of K-Pop and K-Drama. The media jumped in to publish prognosis on the Korean wave and its effect on the rest of Korea, and some of the academia also chimed in, suggesting ways to further market the Korean culture to the world. Koreans went wild at the prospect of Korean culture going "west" and starting its grand "takeover" of the world's culture. They took pride in referring to themselves as the "cultural leaders."

The danger and precariousness of the Korean desire for cultural dominance present in the new hallyu discourse is obvious. Many commentators have raised criticisms against the new hallyu discourse. Supposing that there are three main framework through which to view a trans-national cultural view, cultural imperialism, cultural nationalism, and globalization, the critiques argue that the new hallyu discourse is a product of the first two. They further assert that the rise of such view could stem from Korea's unique experience of colonial occupation under Japan and late but extremely fast economic growth, and that Korea must embrace globalization framework which welcomes cultural openness and pluralism. Culture is a trans-national, pluralistic entity.

We must face up to the reality of Korea's cultural imperialism and cultural nationalism, and start thinking about a new, pluralistic framework in which to discuss hallyu. However, discussing a new framework with only new hallyu discourse in mind could cause us to overlook the fact that the above-mentioned concerns exist as a constant in any trans-national cultural phenomena. This means limiting the discussion to the new hallyu discourse could make the mistake of regarding cultural imperialism and nationalism as a unique concern in Korea. As mentioned above, culture is trans-national but our thoughts are divided by national boundaries. Thus the cultural nationalism and imperialism that often appear in trans-national cultural phenomenon requires a closer look and study as a constant concern in these phenomenon.

This study looks to go further than just simply criticizing cultural imperialism and cultural nationalism, not only by taking the next step in developing critical self-inspection of the new hallyu discourse, but also to broaden the subject of study beyond the hallyu discourse. In specific, this study explores the history of Japanese pop-culture influx in Korea and its cultural discourse over time. If the hallyu discourse takes the form of pride in the rising popularity of one's own 
culture, the discourse on Japanese pop-culture entering Korea takes the form of anxiety about foreign culture invading one's own culture. In Korea's history of cultural assimilation and evolution, Japan's position is particular; Korea was forced to deny and hide Japan's major influence on Korea's culture as a natural reaction against occupation under Japan. This hide-and-deny attitude manifested itself in President Park Chung-Hee's ban on Japanese popular culture from 1965. Until its end in 1998, the two countries' cultural exchange was distorted for 33 years. While officially banned and openly criticized for its obscenity and substandard quality, unofficially there was an active black market practice importing Japanese pop-culture. Discussion surrounding Japanese pop-culture always involved a plethora of nationalistic remarks. To sum up, the discourse on Japanese culture in Korea is an appropriate example to study "nationalistic anxiety" permeating "trans-national culture." This study will compare the discourse that appeared as Japanese culture entered that of Korean with the new hallyu discourse, ultimately shedding light on nationalistic characteristic present in cultural assimilation.

To begin, the second part briefly summarizes the history of Japanese pop-culture entering Korea. This is to facilitate understanding for readers who do not have knowledge on the relationship and history of the two countries. In the third part, we look at the discourse that came pouring out when the ban on Japanese pop culture was about to be lifted. These discourses, which generally organize into a couple of trends all stem from the 1960s. This is because it was during the 1960s the Korean society recognized Japanese pop-culture trending in Korea for the first time, which in turn called for the ban. Afterwards, we analyze the discourses from the 1960 s, then conclude by summarizing the earlier discussion and pointing out the connection with the new hallyu discourses.

\section{A HiSTORY OF JAPANESE CULTURE INFLUX INTO KOREA}

Korea gains independence at the end of World War II, in 1945. According to Chang Se-Jin's study, during the 1950s when Korea could not distance itself from its colonial experience, the discourse about Japan usually took the form of denial and retribution [1]. In this period, the discourses showed tendency to deny and call for retribution from not only Japan but also the colonial period in which Japan influenced Korea. A call for complete denial and deletion of cultural development made in Japanese occupation as well as open hatred against Japan was commonplace. This was a manifestation of Koreans' desire for a fresh start from 1945 as ground zero, clearing out Japanese collaborators, and was in line with the first President Rhee Syngman's anti-Japan stance.

This trend could not continue under the onslaught of Japanese pop-culture in the 1960s. Before the Japanese pop-culture boom, in April of 1960 the whole country was calling for democratization and overthrowing of President Rhee's dictatorship and end to fraudulent electoral practices. (Known as 4.19 revolution) The revolution brought about an air of freedom and an end to ban on Japanese culture, (President Rhee's government had banned Japanese pop culture as a part of his sanction on Japan) which started a sudden inflow of Japanese pop culture unprecedented both in its speed and size. This "Japanese gale raging across the nation" was so severe that magazines such as Sasanggye expressed concerns.

The "Japanese gale" came back even stronger after it was briefly reduced in strength after Park Chung-Hee's coup d'état, but finally ended in 1965. At the time Park regime was trying to establish diplomatic relationship in order to gain funds for economic development. But many citizens judged the aid agreement and apology Park regime got from japan as insufficient, and took to the street protesting the Park regime as "anti-patriotic regime." Interestingly enough, President Park bans all Japanese popular culture just as the Korean-Japanese relationship normalized.

Afterwards, Japanese culture was officially banned but continued to spread itself through black markets and copying, existing as a paradox in the midst of increasing Korea-Japan interaction and official ban. The ban was limited to Japanese "popular culture" but this affected the whole of discourse on Japan, leading it to conclude that Japanese culture is decadent and perverted. 15 years after the ban was lifted in 1998, such distorted view on Japan has not dissipated completely. In the next part, we look at the discourses on Japanese pop-culture during the 1990s when the ban was being lifted, then traces our steps back to the 1960 s.

\section{Two Frames Discussing JAPANESE Pop CUlture: NATIONALISM AND ELITISM}

\section{A. Contradiction Present in Koreans' Discourse on Japanese Popular Culture}

After partially lifting the ban on Japanese cultural exports in April 1998, the whole nation was in turmoil over the issue of this door opening. This marked the first time since 1965's embargo, imposed by the Park Chung-Hee government, that Japanese cultural goods would legally enter the country. In 2005, one year after the ban on CDs and DVDs was lifted; Hong Sung-tae summarized the result of the heated controversy as follows:

The core of the dispute over the opening of Japanese pop-culture was not the choice to open or not, but the question of when to open and how much to open. Also, what really mattered was the problem of economic benefits and losses, not a political or cultural problem. Sorrowful indignation or unconditional resistance toward Japan had not been observed and most discussion, assuming the opening, was focused on its economic impact rather than its cultural influence: The era has changed [2].

The fact that Hong pays such close attention to the "changed era" raises questions about the previous era. Hong suggests that this previous era was a time in which "sorrowful indignation or unconditional resistance" was dominant, and concerns about "its cultural influence" were paramount when Korea began to speak of Japan or its culture. Although Hong says that the focus was on timing, regulation, and extent, he is also suggesting that no one disagreed that Japanese culture needed to be regulated to some degree. It is necessary to recall that aside from communist countries, 
Japan was the only nation whose popular culture had been totally prohibited in Korea. It shows that Koreans in the 1990s took Japan's exceptional case for granted and agreed that the lifting should be carried out under appropriate regulation.

There were two reasons justifying the regulations at that time. First, it was thought that Japan's pop-culture was too bizarre and violent and would have a negative impact on Korean customs. Second, due to the strength of Japan's economy and technological advancements, some worried that they would encroach upon the foundations of the domestic cultural industry and make it collapse. Within these two rationalizations lies a contradiction. The former is saying that Japan is culturally behind Korea with their vulgar and bizarre cultural practices, while the latter expresses a fear that Japan is more advanced than Korea. To reconcile these two contradictions, we should either draw some boundaries that show Japan as partly vulgar but generally more sophisticated, or bad in quality but better in technology and industry; or we should call out the masses in order to say that the domestic cultural industry can collapse under Japanese pressure since the masses enjoy such a low-grade culture as Japan's. Both strategies might have been used; it was an inevitable contradiction when Koreans tried to discuss anything about Japan including its pop-culture. Koreans generally felt that Japanese cultural products were incredibly vulgar while simultaneously thinking that Japan was far ahead of Korea at the same time.

In Kwak Dae-won's Copying Japanese Pop-Culture [3], the chapter Cartoon provides clues to the origins of such a contradiction. Kwak first asks, "why is Japanese manga more interesting than Korean manga?" The author answers that strong national regulations on manga in Korea had limited the creativity of artists in styles, materials, and themes. Korea had experienced decades of dictatorial rule, and this historical misfortune had increased the pop-culture gap between Japan and Korea. This gap pushed Korean readers toward the more entertaining Japanese manga and also increased the practice of copying -- both copying stories and rewriting them as their own and illegally printing them in Korea. Interestingly, Kwak maintains a contradiction (similar to the one discussed previously) that Japanese pop-culture is vulgar and violent, whose exposure to Korea could cause harm, while at the same insisting that its quality is much higher than that of Korea's.

Cheon's paper explores the phases of Japanese pop-culture importation beginning in April 1960, when student-led protesters pushed President Rhee to resign providing a momentary hope of democratic rule before Park Chung-hee's coup later that year [4]. This Japanese wave ends in July 1965 , when the cultural embargo was imposed paradoxically after the normalization of diplomatic relations between Korea and Japan. It is important to examine this period and determine the context surrounding the contradictory situation of diplomatic normalization alongside a cultural embargo. We now turn to examine this particular period.

\section{B. Elitist Attack and Nationalistic Concerns on Japanese Popular Culture Consumption by the Masses}

Due to the two nations' geographic proximity, cultural exchange had always been a natural occurrence, although Japan's influence certainly increased in the late 19th and early 20th centuries as it prepared for and carried out colonial rule. However, in 1960 student revolts jolted the peninsula into a frenzy of revolution and liberation. The entire nation became affected by the political movements at that time and everything was affected from pop-culture to high culture. According to Cheon's paper, which analyzed Japanese literature translation trends of that time, there was an increase in interest in Japanese literature. Cheon posits that the university students emerging from the student protests of 1960 played an important role in this boom. He says that they embraced Japan's literature as "a mediation of cross-border modernity" and an embodiment of 'post-war sensitivity.' Cheon insists that their enjoyment did not run counter to nationalism despite the fact that it was frequently criticized as 'senseless' by disputants of nationalistic positions-if anything, as we can see from the fact that Japanese culture boom of that time co-existed with the third-world nationalism which flew into Korea right after, it was more of an increased craving for modernity emerging with the new nationalism. Nevertheless, the discourses of the time over such a phenomenon can be summarized in 'nationalist antipathy' and 'criticism toward the masses.' A strong elitism is found in the wariness toward Japanese culture because its basic premise is that masses are immature.

The boom in Japanese culture came back stronger in 1962 after a short latent period in 1961 after the military coup led by Park Chung-hee. There were several best selling books, and Ishizaka Yojiro's novel was not only a bestseller, but was also read on the radio and dramatized as a movie. The Japanese Wave, or Ilryu, continued.

In 1964, the uprising of anti-Japan nationalism reached its peak against the Park Chung-Hee government's Korean-Japanese conference. Ironically the Japanese boom driven by the young students and the masses also peaked. One distinguishing aspect of Japanese discourse at this time was that there was concern about Japan's cultural invasion: A worry about obliterating Korean ethnicity and erasing its national spirit. In this way, a vague fear toward Japan spread along with the normalization of diplomatic relations, which shows that there existed an "awareness and deep anxiety of Korea's objective weakness in its existence and sovereignty." Cheon argues that the precariousness of the system manifested itself in the shape of the anxiety that originated from the colonial experience.

In June 1965, in spite of the opposition movement, Korea and Japan signed an agreement that normalized diplomatic relations between the two nations. The day after the finalization, President Park Chung-Hee imposed various regulations on foreign cultural imports including pop-music and publications. Park's rationale was based on the pretext of protecting the nation from an alien culture. He regarded the arguments of his opponents as a product of ethnic complex suggesting that they should gain more confidence. Meanwhile, Japanese literature continued to be imported showing that it was only pop-culture, and not high culture, was the only segment to be susceptible to the new regulations. Yet, despite the official prohibitions, smuggling continued. Since 1965, Japanese pop-culture was officially banned, but 
it continued to exist on the sly.

The reason why the government had to carry out this contradiction was that Park needed to show his nationalistic attitude to the people in the administration to counter the anti-Japanese nationalism of his opponent's side. In other words, it was nationalist complementary measures taken in order to conceal 'anti-nationalism' of the hasty Korea-Japan diplomatic normalization. He was sacrificing the popular culture of Japan to deal with people's fears that "Japan is back." He strategically used it to obliterate the stigma of him being 'anti-nation' and 'comprador.' In the meantime, the elite-ruling class criticized the masses and their enjoyment of Japanese pop-culture pointing out its vulgarness in response to the treatment of the government. However, given that they had always been the ones most enthusiastic in absorbing Japan's various cultural products as bilingual speakers since the colonial period, their discourses surrounding the policy banning Japanese pop-culture seem to have played in order to disguise their own anti-nationalism and anti-populism. These are all cases of an attempt to convert a political problem or fear about growing body of the masses to an attack on the popular culture by using nationalism.

In the 2010s, as hallyu gained momentum in Japan, "anti-Korean wave" movement also became visible. The conservative Japanese who support the anti-Korean wave movement are hostile towards the hallyu movement, Koreans and zainichi(referring to Koreans who were born/raised in Japan). At the first glance, this is simply a reaction against the rising popularity of hallyu. After the Fukushima disaster of 2011, however, the new worries concerning the safety of current social system bolstered nationalistic attitudes in Japan, and the anti-Korean wave movement aligned itself with the new nationalistic tendency. This is similar to the dominant anti-Japanese discourse that rose up in the 1960s when Japanese culture poured into Korea. Both cases try to channel the anxiety about cultural assimilation and political trouble into an attack against the other's popular culture.

\section{Conclusion: THE Similarities AND DifFERENCES} BETWEEN THE DisCOURSES ON JAPANESE POP CULTURE AND HALLYU

The effect of nationalism on trans-national culture is three-dimensional and complex. The cultural nationalism frame needs a deeper consideration before simply being criticized and shunned. For example, the nationalistic perspective looking at the Japanese pop culture boom in the 1960s has a sense of inevitability. How to look at Japan, which colonized Korea, was a matter requiring serious discussion in the 1960s, as well as just political and diplomatic tasks. Seeing the old haunts of Japanese occupation and being afraid, and trying to stop the return of Japanese occupation using nationalistic rhetoric was a way to progress this national discourse.

The Japanese pop-culture was not confined to the fields of anti-Japanese nationalism. This culture was Japanese in nature, but also a manifestation of modernity. In the aftermath of 4.19 revolution, the Japanese pop-culture so spread itself to the public. The ordinary citizens shared the intelligentsia's anti-Japanese conviction, but at the same time enjoyed the Japanese pop-culture. Much of the new information and knowledge came in through Japan in the 1960s; even the intellectuals could not help but be a part of the very movement they disapproved. Nevertheless they separated themselves from the public, and criticized the public consuming Japanese pop-culture.

President Park's regime hastened to normalize diplomatic relationship with Japan in order to gain finances for economic development. The people who wanted a sufficient apology and reparation disapproved the regime's actions and labeled Park's regime a "Comprador regime." The government took "nationalistic" measures of banning obscene and inappropriate Japanese pop-culture, and so stood against political opposition. Park regime sacrificed popular culture in order to defend against the opposition's nationalism, in turn achieving regime's stability.

If we are to avoid one-dimensional criticism of cultural nationalism, the real problem of hallyu discourse is the elitist perspective. Kim Su-ah's paper has revealed the characteristics and structure of 2012's Hallyu discourse by analyzing documentary programs celebrating the success of the new Hallyu and K-POP of Korea's main domestic broadcasting stations. In this paper, her main point is that the usual narrative of these programs focuses on the passion of the idol stars and their global fans, typically overlooking the aspect of production, so that its effect is similar to that of the neo-liberal success story. However, in the extension of the discussion so far, the part we should examine more carefully is as follows:

There is a need to focus on the node between Korean culture and the K-POP in those documentaries. They basically claim that K-POP's appeal be connected to an interest for the other parts of Korean culture. This claim is affected by the Lee Myung-bak government's consistent cultural policy-continuous efforts to connect the new Korean wave with the traditional culture. To the administration and producers of the documentaries, K-POP has a meaning as long as it evoke the international interest toward the traditional culture of Korea [5].

This attitude that points to the other side again and again when talking about K-POP, which is related to the policy, also has relevance to elitist and conservative points of view toward popular culture. It reveals its assumption that popular culture is just a means of leading people to the traditional culture, not a real culture. Kim says it is the reason why those documentaries repeatedly show how fans of K-POP eventually turn to the world of traditional Korean culture, whereas they do not deeply discuss the K-POP itself. This strategy of distinguishing pop-culture from Culture is also found in the rhetoric of the Park Chung-Hee government, as well as the ruling elite of that time who criticized the masses, when prohibitions on Japanese cultural products were banned to different degrees based on high culture and pop-culture. Is it possible to regard the producers, viewers, and participants of these late night domestic documentaries as the elite ruling class? If so, their point of view towards pop-culture seems very coherent.

Yet, a certain embarrassment is detected from the Hallyu discourse of these programs. The popularity of Korean popular culture continues to grow on the world stage, and 
Korea's traditional, or high, culture can only be spread through this pop-culture phenomenon. This effect seems to make the cultural elitists embarrassed. Instead of providing a detailed analysis of K-POP, the documentaries focus on a few Westerners whose interests in Korea have progressed beyond K-POP, and in this way hopes that the world will start to see the rich Korean culture. They are trying to make up for the embarrassment. When it comes to Hallyu, the ruling elite is no longer able to diminish the pop-culture, and this might be a discursive difference between the Korean Wave and the Japanese Wave: A puzzled feeling from seeing a "growing body of the masses."

\section{REFERENCES}

[1] S. Chang, "Imagined aerica and self-representation of Korean literature in 1950s," Ph.D. dissertation, Dept. Korean Literature, Yonsei Univ., Seoul, Korea, 2008.
[2] S. Hong, "Culture alitics of Japanese pp-culture iport lberalization," in the Cultural Formation of Modern Korean Society, Seoul, Korea: Hyunsil Munhwa, pp. 318-339, 2006

[3] D. Kwak, "Why Japanese Mnga is interesting," in Copying Japanese Pop-Culture, Seoul, Korea: Trees and Forest, pp. 187-210, 1998.

[4] J. Cheon, "Why did 'the year 1960' like Japanese culture," in Asking the Year 1960, Seoul, Korea: Imagine 1000, pp. 509-538, 2012.

[5] S. Kim, "Television discourse on k-pop and k-pop idol stars' passion," Journal of Communication Research, vol. 50, no. 1, pp. 45-83, Feburary 2013.

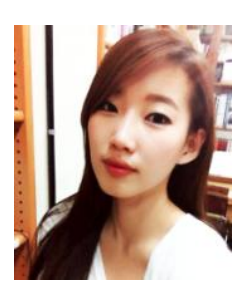

Jimin Jung was born in Daegu, Korea, on August 6 , 1989. She is a graduate student in the master's course in Department of Korean Language, Literature, and Cultural Studies at Yonsei University, Seoul, Korea. She is now preparing her dissertation of master with the same subject this paper is dealing with Japan in the 1960 's Korea as a discursive task of post-colonial Korea. 